\title{
Evaluation of the development of five Sedum species on extensive green roofs in a continental Mediterranean climate
}

\begin{abstract}
Because of their easy implementation and low maintenance, extensive green roofs have become established during the last few decades as one of the best options for integrating vegetation on the built environment. The success of these systems involves having of a plant species palette well adapted to extreme conditions, especially in drought environments. Among the available ones, the Sedum genus has stood out due to its tolerance to climate extreme conditions and its use has been widespread throughout the world. In previous research, efforts have been mainly concentrated on selecting the most drought tolerant Sedum species, without considering other important parameters for the suitable provision of ecosystem services from the green roof, such as coverage capacity, shape and structure or growth strategy, among others. In this study, five species of Sedum (Sedum album, S. sediforme, S. sexangulare, Sedum spurium cf. 'Coccineum' (syn. Phedimus spurius cf. 'Coccineum') and Sedum spurium cf. 'Summer Glory' (syn. Phedimus spurius cf. 'Summer Glory') were tested in a dry continental Mediterranean climate with the aim of observing their patterns of growth and development. Results revealed that Sedum album, S. sediforme, S. sexangulare are recommended species for their use on extensive green roofs in this climate, whereas both varieties of $S$. spurium, particularly var. "Coccineum", present some limitations for their use, basically due to their shape, plant structure, pigmentation and lack of adaptation to winter conditions. Shape Index could be an adequate tool for decision-making in the selection of plant species in the design of green roofs because it provides information not only about the shape and size but also related to the growth strategy of these plants.
\end{abstract}

\section{Key words}

Extensive green roofs, sedum species, plant cover, shape index, nursery effect, drought tolerance.

\section{Introduction}

During last few decades, green roof systems have been established all over the world as important nature-based urban solutions that present several benefits over conventional grey solutions, not only from the environmental point of view but also as cost-effective, aesthetic and socially valuable solutions (European Commission, 2015). Green roofs, along with other green urban infrastructures, provide several ecosystem services at both the building and city level (Pérez and Perini, 2018). At the building level, green roofs improve the building envelope performance, providing energy savings (Coma et al, 2016) and acoustic insulation. In addition, they increase the durability of waterproofing membranes and contribute to the recovery of open spaces within the urban environment, where landscaping and gardening, food production and social activities can therefore be developed. At the urban level, the benefits provided by green roofs are also significant: they mitigate the urban heat island effect, contribute to storm 
water management, reduce noise and air pollution, support biodiversity, offer spaces for recreation and human well-being, and improve city residents' health (Pérez and Perini, 2018).

There are two established approaches toward green roofs, extensive and intensive systems, although intermediate solutions may also be found (FLL, 2008). This general classification derives from their multilayer structure that comprises, from top to bottom, the following layers: vegetation, substrate, filter, water drainage-storage, protection and water retention, and finally the root barrier and waterproofing layer. From this general multi-layer structure, the different typologies of green roofs are furtherly distinguished in order to achieve the desired landscaping and environmental objectives and the selected plants' requirements. Table 1 shows the main green roof typologies and characteristics.

Table 1. Green roof typologies and main features. Adapted from (FLL, 2008)

\begin{tabular}{|l|l|l|l|}
\hline Parameter & Extensive & Semi-intensive & Intensive \\
\hline $\begin{array}{l}\text { Weight at maximum } \\
\text { water capacity }\end{array}$ & $50-150 \mathrm{Kg} / \mathrm{m}^{2}$ & $120-350 \mathrm{Kg} / \mathrm{m}^{2}$ & $>350 \mathrm{Kg} / \mathrm{m}^{2}$ \\
\hline $\begin{array}{l}\text { Substrate layer } \\
\text { thickness }\end{array}$ & $6-20 \mathrm{~cm}$ & $10-25 \mathrm{~cm}$ & $>25 \mathrm{~cm}$ \\
\hline Plant typologies & $\begin{array}{l}\text { Succulent, herbaceous } \\
\text { and grasses }\end{array}$ & $\begin{array}{l}\text { Herbaceous, grasses } \\
\text { and shrubs }\end{array}$ & $\begin{array}{l}\text { Grasses, shrubs and } \\
\text { trees }\end{array}$ \\
\hline Slope & $<100 \%$ & $<20 \%$ & $<5 \%$ \\
\hline Irrigation & Never or periodically & Periodically & Regularly \\
\hline Maintenance costs & Low & Moderate & High \\
\hline Implementation costs & Low prigh & $\begin{array}{l}\text { To } \\
\text { landscaping, aesthetics } \\
\text { and recreational uses }\end{array}$ \\
\hline Purpose & $\begin{array}{l}\text { To provide ecosystem } \\
\text { services minimizing } \\
\text { environmental impacts } \\
\text { and extra costs }\end{array}$ & Intermediate purposes & Middle \\
\hline
\end{tabular}

Intensive green roofs, commonly called 'roof gardens', are designed to prioritize landscaping, aesthetics and recreational uses. They host a large range of ornamental plant species including shrubs, bushes and trees, which influence these systems' weight, build-up heights and costs. Extensive green roofs, on the other hand, are mainly developed to provide ecosystem services, minimizing environmental impacts and extra costs. Thus, they are distinguished by their minimal maintenance requirements, and the plants selected tend to be very tolerant to local climatic conditions and of the selfgenerative type (Wong et al., 2007).

Therefore, the plant species that can be used in a green roof for a specific project will strongly depend on the type of green roof (extensive, semi-intensive or intensive) that it is possible to apply to the roof construction system of the given building, as well as these species' adaptability to local climatic conditions. Moreover, the facility with which maintenance procedures may be applied to the roof is also a factor: greater access will contribute to plant development and, consequently, guarantee plant survival during the operational phase.

In a general and simplified way, Table 2 summarizes the main factors and parameters influencing plant growth and development on green roofs, and therefore the key aspects to be considered when choosing the most appropriate species for this use. 
Table 2. Main influencing factors for plant growth and development on green roofs

\begin{tabular}{|c|c|c|c|}
\hline $\begin{array}{l}\text { Influencing } \\
\text { factors }\end{array}$ & & Parameters & Observations \\
\hline \multirow[t]{2}{*}{ Climate } & Macro-climate & $\begin{array}{l}\text { Solar radiation, } \\
\text { temperature, } \\
\text { precipitation, relative } \\
\text { humidity, dominant } \\
\text { winds }\end{array}$ & $\begin{array}{l}\text { City level } \\
\text { Köppen climate classification, which is } \\
\text { based on temperature and precipitation, is } \\
\text { a suitable reference when working with } \\
\text { vegetation (Kottek et al., 2006). }\end{array}$ \\
\hline & Micro-climate & $\begin{array}{l}\text { Shadows, air currents, } \\
\text { smoke emissions and } \\
\text { residual heat from the } \\
\text { building }\end{array}$ & Building level \\
\hline \multirow[t]{4}{*}{ System } & Substrate layer & $\begin{array}{l}\text { Thickness and } \\
\text { composition }\end{array}$ & $\begin{array}{l}\text { Physical support for plants. Water } \\
\text { retention capacity, amount of nutrients } \\
\text { and their availability for plants }\end{array}$ \\
\hline & $\begin{array}{l}\text { Drainage and } \\
\text { storage layer }\end{array}$ & $\begin{array}{l}\text { Thickness, shape and } \\
\text { composition }\end{array}$ & $\begin{array}{l}\text { Water retention capacity and its } \\
\text { availability for plants. Drainage capacity. }\end{array}$ \\
\hline & Irrigation system & $\begin{array}{l}\text { Availability and } \\
\text { quantity applied }\end{array}$ & \\
\hline & $\begin{array}{l}\text { Density of } \\
\text { plantation and } \\
\text { palette of species }\end{array}$ & $\begin{array}{l}\text { Competition and } \\
\text { nursery effect between } \\
\text { plants }\end{array}$ & \\
\hline \multirow[t]{4}{*}{ Maintenance } & & Nutrients supply & \\
\hline & & Pruning & \\
\hline & & Pest and weed control & \\
\hline & & Weed removal & \\
\hline
\end{tabular}

After having analysed Tables 1 and 2 it can be deduced that the real challenge arises specifically for extensive green roofs with small substrate thicknesses, and usually with minimum levels of maintenance and irrigation, in which the selection of plant species implies the consideration of multiple variables. As a consequence, previous research experiences have revealed the difficulty of achieving $100 \%$ coverage on extensive green roofs in extreme climates such as the dry continental Mediterranean climate (Csa; warm temperate; dry summer; hot summer) (Pérez et al., 2015; Bevilacqua et al., 2015).

In this context, the ability of plant species to develop under these extreme conditions is one of the most concerning issues for all parties involved, i.e. the scientific community, manufacturers and owners. Essentially, the selection of plant species must be appropriate to guarantee survival in the face of the various adversities the plants may encounter: reduction of water consumption due to sustainability requirements, long periods of drought, or an irrigation system failure.

According to Vijayaraghavan (2016), and considering the common extreme environment on rooftops, the favourable characteristics of vegetation for extensive green roofs are: the ability to withstand drought conditions, to survive under minimal nutrient conditions, to achieve good ground coverage, to require little maintenance, to present rapid multiplication with short and soft roots, and to be capable of phytoremediation.

Some previous studies highlight that Sedum species are the most appropriate plants to apply on extensive green roofs, due to their shallow root systems, Crassulacean acid metabolism (CAM), and their efficient water use, as well as their tolerance to extreme conditions of heat and drought (Ondoño et al. 2015; Benvenuti and Bacci, 2010). 
After performing a comprehensive literature review, Table 3 summarizes the number of times that each Sedum species has been used in different studies, as well as the author and year. The main Sedum species used in previous investigations are S. acre, S. album, S. dasyphyllum, S. hispanicum, S. kamtschaticum, S. pulchellum, S. reflexum, S. rupestre, S. sediforme and S. spurium.

Table 3. Most used Sedum species in previous green roof research

\begin{tabular}{|c|c|c|c|c|c|c|c|c|c|c|c|c|c|c|c|c|c|c|c|c|c|c|c|c|c|c|c|c|c|c|c|}
\hline & కి & 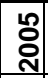 & กั & ¿্స: & సิ & 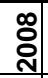 & : & : ڤ్ & \begin{tabular}{|l|} 
: \\
\end{tabular} & :े & 일 & 영 & 웜 & & กิ้ & กิ้ & సิ่ & & مै: & & &  & 离 & & & & & & 露 & & \\
\hline &  & 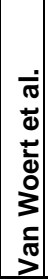 &  & 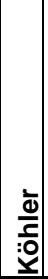 &  & 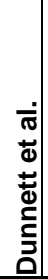 &  & 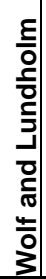 & 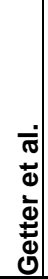 & 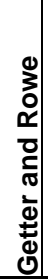 &  & 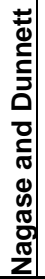 & 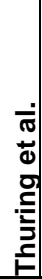 &  & $\begin{array}{l}\overline{\bar{d}} \\
\overline{0} \\
\bar{J} \\
\overline{0} \\
\bar{\sigma} \\
\bar{d} \\
\bar{v} \\
\overline{0}\end{array}$ & 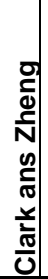 & 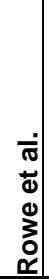 &  & 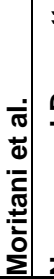 & 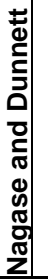 &  & 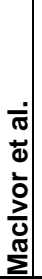 &  & 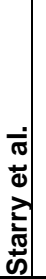 & 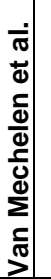 & 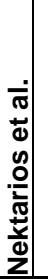 & 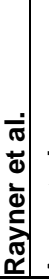 & & &  & 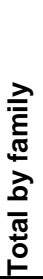 \\
\hline S. acre & $\mathrm{x}$ & $x$ & $x$ & $x$ & $x$ & $x$ & $x$ & $x$ & & & $\mathrm{x}$ & & & & & $x$ & $x$ & & & & $x$ & $\mathrm{x}$ & $\mathrm{x}$ & & $\mathrm{x}$ & & $x$ & & & 6 & \\
\hline S. acre 'Minor' & & & & & & & & & & & & $x$ & & & & & & & & & & & & & & & & & & 1 & \\
\hline S. acre 'Oktoberfest' & & & & & & & & & $x$ & & & & & & & & & & & & & $x$ & & & & & & & & 2 & 19 \\
\hline S. album & $\mathrm{x}$ & $x$ & $x$ & & & & $\mathrm{x}$ & & & & & & $x$ & $x$ & $\mathrm{x}$ & $\mathrm{x}$ & & & & $\mathrm{X}$ & & $x$ & & $x$ & $\mathrm{X}$ & & & & & 2 & \\
\hline S. album 'Bella d'Inverno' & & & & & $x$ & & & & & & & & & & & & $x$ & & & & & & & & & & & & & 2 & \\
\hline S. album 'Coral carpet' & & & & & & & & & $\mathrm{x}$ & & & $x$ & & & & & & & & & & & & & & & & & & 2 & 16 \\
\hline S. dasyphyllum & & & & & & & & & & & & & & & & & & & & & & & & & $x$ & & & & & 1 & \\
\hline S. dasyphyllum 'Burnati' & & & & & $\mathrm{x}$ & & & & & & & & & & & & $\mathrm{x}$ & & & & & & & & & & & & & 2 & \\
\hline $\begin{array}{l}\text { S. dasyphyllum 'Lilac } \\
\text { Mound' }\end{array}$ & & & & & $\mathrm{x}$ & & & & & & & & & & & & $x$ & & & & & & & & & & & & & 2 & 5 \\
\hline S. hispanicum & & & & $x$ & $x$ & & & & & $x$ & & & & & & & $x$ & & & & & $x$ & & & & & & & & & 5 \\
\hline S. kamtschaticum & & & & & $x$ & & & & $x$ & & & & & & & & $x$ & $\mathrm{X}$ & $x$ & & & $x$ & & $x$ & & & & & & 7 & \\
\hline $\begin{array}{l}\text { S. kamtschaticum } \\
\text { 'ellacombianum' }\end{array}$ & $\mathrm{x}$ & $x$ & & & & & & & & & & & & & & & & & & & & $x$ & & & & & & & & 3 & \\
\hline $\begin{array}{l}\text { S. kamtschaticum var. } \\
\text { Floriferum }\end{array}$ & & & & & & & & & & & & & & & $\mathrm{x}$ & & & & & & & & & & & & & & & 1 & 11 \\
\hline S. pulchellum & $x$ & $\mathrm{x}$ & & & & & & & $\mathrm{x}$ & & & & & & & $x$ & & & & & & $\mathrm{x}$ & & & & & & & & & 5 \\
\hline S. reflexum & $x$ & $x$ & & $x$ & $x$ & & & & $x$ & & & & & & & $\mathrm{x}$ & $x$ & & & & & $\mathrm{x}$ & & & & & & & & 8 & \\
\hline S. reflexum 'Blue Spruce' & & & & & & & & & & $x$ & & & & & & & & & & & & & & & & & & & & 1 & 9 \\
\hline S. rupestre & & & $\mathrm{x}$ & $\mathrm{x}$ & & & & & & & & $\mathrm{x}$ & & $x$ & $x$ & & & & & & & & & & & & & & & 5 & \\
\hline S. rupestre 'Angelina' & & & & & & & & & & $x$ & & & & & & & & & & & & & & & & & & & & 1 & 6 \\
\hline S. sediforme & & & & & $\mathrm{x}$ & & & & & $x$ & & & & & & & $\mathrm{x}$ & & & & & & & & & $x$ & $\gamma$ & $x \times$ & & & 6 \\
\hline S. sexangulare & & & $\mathrm{x}$ & $\mathrm{x}$ & & & & & & $\mathrm{x}$ & & & $\mathrm{x}$ & $\mathrm{x}$ & $x$ & $x$ & & & & & & $\mathrm{x}$ & & & & & & & & & 8 \\
\hline S. spurium & & & & $\mathrm{x}$ & & & & $x$ & & & $x$ & & & $x$ & $x$ & & & & & & & & & & & & & & & 5 & \\
\hline S. spurium 'Coccineum' & $\mathrm{x}$ & $x$ & & & & & & & $x$ & & & $\mathrm{x}$ & & & & & & & & & & $x$ & & & & & & & & 5 & \\
\hline $\begin{array}{ll}\text { S. spurium 'Dragons } \\
\text { Blood' }\end{array}$ & & & & & & & & & & & & & & & & $\mathrm{x}$ & & & & & & & & & & & & & & 1 & \\
\hline S. spurium 'John Creech' & & & & & & & & & & $\mathrm{x}$ & & & & & & & & & & & & & & & & & & & & 1 & \\
\hline S. spurium 'Royal Pink' & $x$ & & & & & & & & & & & & & & & & & & & & & & & & & & & & & 1 & \\
\hline S. spurium 'Summer Glory' & & $x$ & & & $\mathrm{x}$ & & & & & & & & & & & & $x$ & & & & & $x$ & & & & & & & & 4 & \\
\hline S. spurium 'voodoo' & & & & & & & & & & & & & & & & & & & & & & $\mathrm{x}$ & & & & & & & & 1 & 18 \\
\hline
\end{tabular}
green roofs' extreme conditions, the most determining factor being their ability to tolerate 
water shortages. From the results, it has been demonstrated that Sedum species are able to survive in conditions of prolonged events of extreme drought, even when the substrate layer is very thin and therefore unable to retain moisture. In addition to these abilities, some references relating to the ecosystem services provided by Sedum species, such as water runoff control, energy savings, etc., were also found.

However, beyond plant survival studies, there is a lack of knowledge regarding the patterns of growth and development of the different species of Sedum used on green roofs. This topic is of special interest because it influences their ability to provide optimal vegetal coverage and consequently not only to guarantee roof sustainability (i.e. the survival of plants through the nursery effect (Van Mechelen, 2014), but also to properly provide the associated ecosystem services (Pérez et al., 2015; Bevilacqua et al., 2015). Thus, in this paper five species of Sedum under dry continental Mediterranean climate conditions ( $\mathrm{Csa}$ ) were experimentally studied. The main aim consisted in observing their growth patterns and specific development in a green roof system to draw conclusions about their individual potential to contribute to the rooftop coverage, sustainability of the green roof and also its linked ecosystem services.

\section{Material and methods}

\subsection{Site of the study}

130 The study was conducted in the botanical garden of Lleida, Spain (Arboretum Pius Font i Quer, $\left.41^{\circ} 37^{\prime} 40.0^{\prime \prime} \mathrm{N} 0^{\circ} 36^{\prime} 07.3^{\prime \prime} \mathrm{E}\right)$. The local climate is dry continental Mediterranean with a mean annual temperature of $15^{\circ} \mathrm{C}$ and average annual rainfall of approximately $385 \mathrm{~mm}$, concentrated in spring and autumn. A summary of the annual weather data from the study is presented in Table 4.

Table 4. Climatic data during the year of study

\begin{tabular}{|l|c|c|c|c|c|c|}
\hline & T & TM & Tm & DTV & R & H \\
\hline January & 3.8 & 9.1 & -0.1 & 9.2 & 12.1 & 81 \\
\hline February & 5.8 & 12.4 & 0.2 & 12.2 & 20.8 & 70 \\
\hline March & 11.5 & 18.6 & 5.3 & 13.4 & 29.2 & 65 \\
\hline April & 14.4 & 22.8 & 6.7 & 16.1 & 4.9 & 62 \\
\hline May & 19.2 & 28.1 & 11 & 17.1 & 3.7 & 55 \\
\hline June & 24.5 & 33.0 & 15.3 & 17.4 & 23.8 & 58 \\
\hline July & 28.0 & 36.3 & 19.2 & 16.5 & 64.7 & 56 \\
\hline August & 24.0 & 32.3 & 17.4 & 15 & 16.1 & 65 \\
\hline September & 18.8 & 26.7 & 12.4 & 14.3 & 11.7 & 69 \\
\hline October & 15.1 & 22.7 & 8.9 & 13.8 & 6.1 & 74 \\
\hline November & 10.1 & 15.2 & 5.9 & 9.3 & 60.8 & 83 \\
\hline December & $\mathbf{5 . 7}$ & $\mathbf{1 0}$ & $\mathbf{2 . 3}$ & $\mathbf{7 . 7}$ & $\mathbf{4 . 1}$ & $\mathbf{9 4}$ \\
\hline Year & $\mathbf{1 4 . 8}$ & $\mathbf{2 2 . 2}$ & $\mathbf{8 . 8}$ & $\mathbf{1 3 . 5}$ & $\mathbf{2 5 8}$ & $\mathbf{6 9}$ \\
\hline Note. \\
T: Monthly/annual temperature average ( $\left.{ }^{\circ} \mathrm{C}\right)$. \\
TM: Monthly/yearly maximum daily temperature average ( $\left.{ }^{\circ} \mathrm{C}\right)$. \\
Tm: Monthly/annual minimum daily temperature average ( $\left.{ }^{\circ} \mathrm{C}\right)$. \\
DTV: Monthly/annual diurnal temperature variation average ( $\left.{ }^{\circ} \mathrm{C}\right)$. \\
R: Monthly/annual precipitation average (mm). \\
H: Relative humidity average (\%).
\end{tabular}




\subsection{Experiment design}

146 The experiment was conducted using two growing tables made of wood with a 147 dimensions of $120 \times 80 \times 20 \mathrm{~cm}$ in which a multilayer green roof system was installed. 148 From the bottom to the top, the green roof consisted of $5 \mathrm{~cm}$ of volcanic gravel material 149 (pozzolana) for the drainage layer, geotextile felt for the filter layer, and $10 \mathrm{~cm}$ thickness 150 for the substrate layer (growing media). The thickness of the whole system was $15 \mathrm{~cm}$. 151 The substrate used was a conventional one for green roofs, with an approximate 152 composition of $40 \%$ compost, $20 \%$ coarse grained sand, and $40 \%$ pozzolana.

153 The two wood growing tables were placed side by side in order to ensure that the 154 differences in the growing patterns were not biased by differences in the environmental 155 conditions.

156 Seedlings of five Sedum species were transplanted from pots to the cultivation samples and placed in the tables in a quincunx planting pattern of $20 \times 20 \mathrm{~cm}$. A total of 5 individuals from each species were planted (Figure 1 and Figure 2). The species selected were Sedum album (White stonecrop), S. sediforme (Pale stonecrop), S. sexangulare 160 (Tasteless Stonecrop). Sedum spurium cf. 'Coccineum' (syn. Phedimus spurius cf. 'Coccineum') (Two-row stonecrop) and Sedum spurium cf. 'Summer Glory' (syn. Phedimus spurius cf.'Summer Glory'). "cf." means that it cannot be affirmed with certainty but the fenotype of the two varieties is compatible to 'Coccineum' and 'Summer Glory'. The selection of these species was based on the knowledge acquired from previous studies and these plants' widespread presence in most of the commercial mixtures for green roofs in the geographical area of the study (Pérez et al., 2015; Bevilacqua et al., 2015). It is worth highlighting that pigmentation changes are common in Sedum species during the different stages of plant development as well as due to temperature changes between seasons. This fact can lead to misinterpretations at the selection of species in the plant nursery phase that may have further consequences on green roof development

172
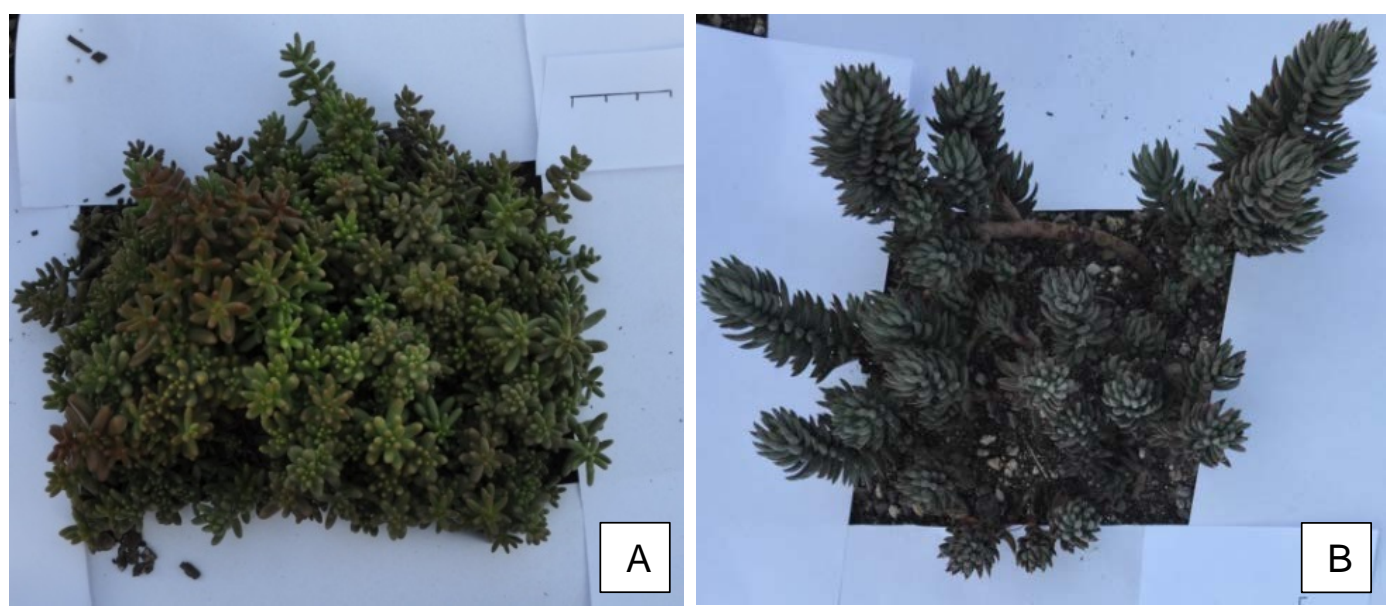



175

176

177

178

179

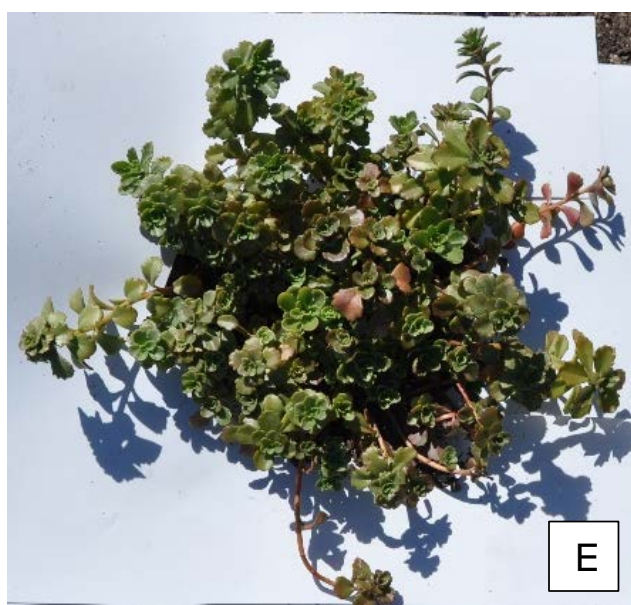

Figure 1. Pictures of the five studied Sedum species. A) Sedum album B) $\mathrm{S}$. sediforme C) $\mathrm{S}$. sexangulare D) S. spurium cf. 'Coccineum' and E) S. spurium cf. 'Summer Glory'

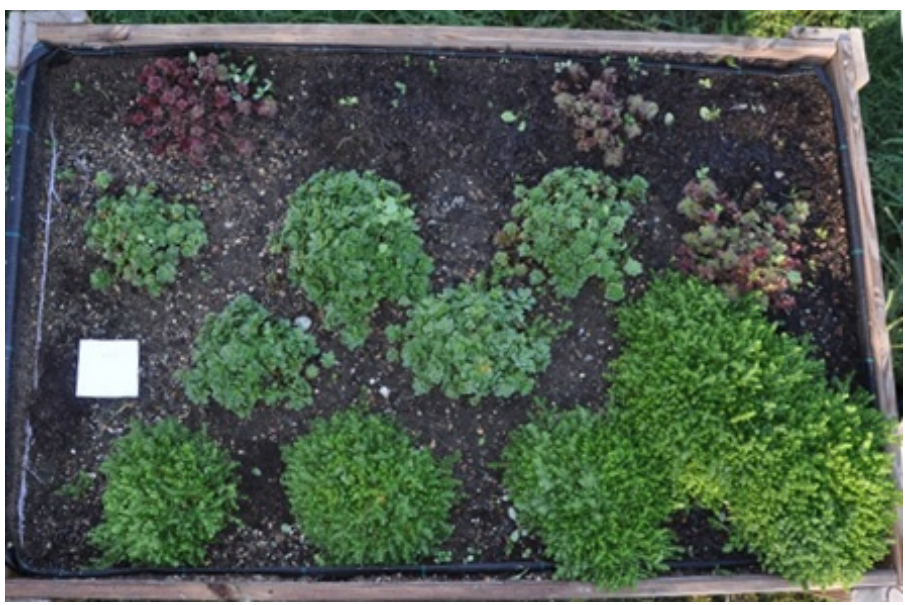

Figure 2. Zenithal view of one of the trays containing five individuals of each species. In the picture Sedum sexangulare, S. spurium cf. 'Coccineum' and S. spurium cf. 'Summer Glory'

The experimental green roof trials took place outdoors in order to conduct the experiment under local climate conditions. The two growing tables were placed side by side to guarantee equal environmental conditions in order to ensure that the differences in the growing patterns were not biased by differences in the environmental conditions. No irrigation was provided during the experiment. However, occasional manual irrigations 
were carried out, both during the first few days after planting to ensure the plants' establishment, as well as on a monthly basis to guarantee the plants' survival in the summer months.

\subsection{Image processing and data analysis}

In order to analyse the growth pattern of the Sedum species, aerial images of the individuals were taken on a monthly basis until the species overlapped (this happened after 11 months). The shape of each individual was digitalized using Image $J$ software (Rasband, 19972018) (Figure 3), and from the binary images obtained the individual area and individual perimeter were measured, to further calculate the following indexes:

- Total area $\left(\mathrm{cm}^{2}\right)$ by species: The sum of the five individual areas of each species in a specific time. The analysis focuses basically on the monthly evolution of this parameter, in order to be able to observe the capacity of growth and surface coverage of each species, as well as the seasonal pattern (Seccion 3.1; Table $5)$.

- Individuals' average area $\left(\mathrm{cm}^{2}\right)$ by species: The average of the five individual measured areas for each species, in a specific time (monthly). These measures allow analysing the growth of each species individually (Section 3.2). The results are presented in two different formats in order to be able to observe the differences between species at a specific time of the year (Figure 4), as well as differences within the same species over time (Table 6). The analysis of differences in both cases was carried out according to ANOVA test with significance $p<0.001$.

In addition, the monthly increase of the individuals' average area in \% (Figure 5), and the increase of individuals' average area compared to the initial individuals' average area by species (Figure 6) were studied in order to provide additional information about the seasonal growth performance of each species.

\section{- Shape index (SI)}

The SI can easily be calculated from the geometric data monthly measured in individuals, to subsequently analyse its monthly evolution by species (Section 3.3, Figure 7). The SI formula is as follows (Garigal and Marks, 1995):

$$
S I=\frac{P i}{2 \sqrt{\pi A i}}
$$

Where $P_{i}=$ perimeter of each individual "i" $. A i=$ area of each individual "i"

Values of SI close to 1 indicate shapes approximated to a circle (maximum compaction) and higher values indicate that the shape is disaggregated. Plant associations of circular shape (shortest perimeter compared to its area patches) are considered to be the most stable and resistant against outer negative effects 




Figure 3. Sedum album. Digitization of the perimeter using Image J software (Rasband, 1997-2018)

\section{Results}

\subsection{Total area by species}

241 Table 5 shows the monthly evolution of the total area $\left(\mathrm{cm}^{2}\right)$ for all the individuals of each 242 species. In the studied period, all the individuals survived except one individual of $S$. 243 spurium cf. 'Coccineum' which died in summer. For the rest of the species, the autumn 244 growth (October) caused the overlap of some individuals. This trend was most noticeable 245 in S. album, whose five individuals merged after the summer period.

Table 5: Total cover $\left(\mathrm{cm}^{2}\right)$ by species.

\begin{tabular}{|c|c|c|c|c|c|c|c|c|c|c|c|}
\hline Species & & Jun. & Jul. & Sep. & Oct. & Nov. & Dec. & Jan. & Feb. & Mar. & Apr. \\
\hline S.album &  & 750.2 & 1088.6 & 1169.6 & 2554.1 & 2620.5 & 2315.1 & 2253.2 & 2692.7 & 2724.4 & 2558.6 \\
\hline S.sediforme & $--=$ & 513.3 & 517.6 & 576.3 & 1751.7 & 1369.9 & 2272.0 & 1354.9 & 1914.0 & 1926.6 & 2446.4 \\
\hline S.sexangulare &  & 588.9 & 727.3 & 734.9 & 1969.0 & 2301.2 & 2224.4 & 2017.5 & 2552.5 & 2569.7 & 2607.2 \\
\hline $\begin{array}{l}\text { S. spurium cf. } \\
\text { 'Coccineum' }\end{array}$ & - " & 457.7 & 408.1 & 267.7 & 462.5 & 343.8 & 314.3 & 279.1 & 422.8 & 426.4 & 506.3 \\
\hline $\begin{array}{l}\text { S. spurium cf. } \\
\text { 'Summer Glory' }\end{array}$ & -- & 866.4 & 786.8 & 665.4 & 1471.1 & 996.6 & 835.5 & 777.0 & 1210.7 & 1271.6 & 1607.0 \\
\hline
\end{tabular}

248

\section{$249 \quad 3.2 \quad$ Individuals' average area by species}

250 Figure 4 and Table 6 show the evolution of the individuals' average area $\left(\mathrm{cm}^{2}\right)$ in each 251 analysed species. The area of the five species in the initial period of the study (June) 252 was very similar (values between 173 and $114 \mathrm{~cm}^{2}$ ) with an individual average area of $253137 \mathrm{~cm}^{2}$. Thus, at the beginning of the study there were no significant differences 254 between the five species (Figure 4). 


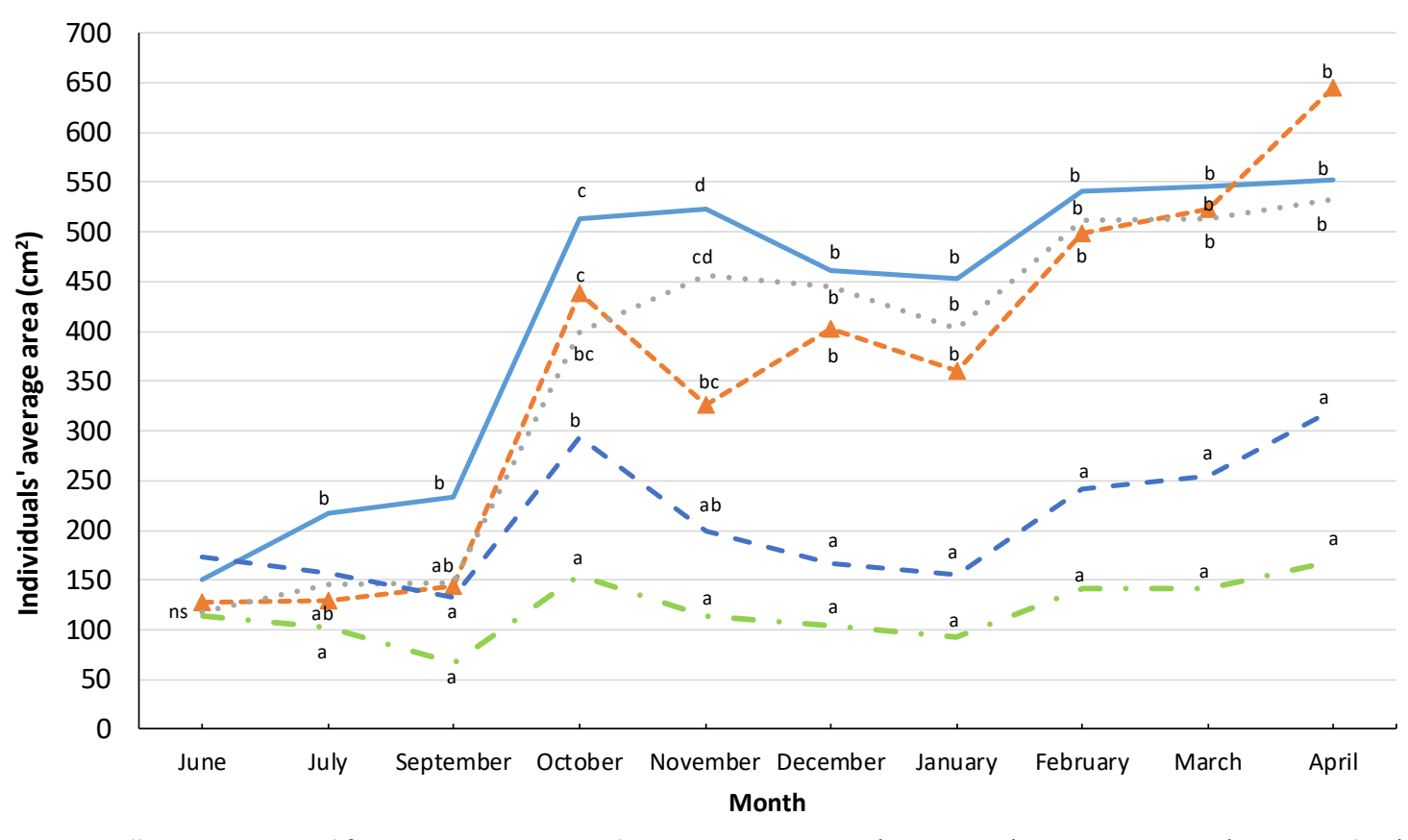

Figure 4: Monthly evolution of the individuals' average area $\left(\mathrm{cm}^{2}\right)$ by species. ANOVA analysis: Different letters mean significant differences $(p<0.001)$ among species on each date. ns= nonsignificant differences.

Table 6. Monthly evolution of the individuals' average area $\left(\mathrm{cm}^{2}\right)$ by species. ANOVA analysis: Different letters mean significant differences $(p<0.001)$ among dates for each species.

\begin{tabular}{lllllllllll}
\hline Species & Jun. & Jul. & Sep. & Oct. & Nov. & Dec. & Jan. & Feb. & Mar. & Apr. \\
\hline S.album & 150 & 218 & 234 & 513 & 523 & 460 & 453 & 542 & 546 & 552 \\
Tukey & $\mathrm{a}$ & $\mathrm{ab}$ & $\mathrm{b}$ & $\mathrm{cd}$ & $\mathrm{cd}$ & $\mathrm{cd}$ & $\mathrm{c}$ & $\mathrm{cd}$ & $\mathrm{cd}$ & $\mathrm{d}$ \\
S.sediforme & 128 & 129 & 144 & 438 & 326 & 403 & 361 & 499 & 523 & 644 \\
Tukey & $\mathrm{a}$ & $\mathrm{a}$ & $\mathrm{a}$ & $\mathrm{bc}$ & $\mathrm{b}$ & $\mathrm{bc}$ & $\mathrm{b}$ & $\mathrm{c}$ & $\mathrm{cd}$ & $\mathrm{d}$ \\
S.sexangulare & 118 & 145 & 147 & 400 & 456 & 445 & 402 & 512 & 513 & 532 \\
Tukey & $\mathrm{a}$ & $\mathrm{a}$ & $\mathrm{a}$ & $\mathrm{b}$ & $\mathrm{b}$ & $\mathrm{b}$ & $\mathrm{b}$ & $\mathrm{b}$ & $\mathrm{b}$ & $\mathrm{b}$ \\
S. spurium cf. 'Coccineum' & 114 & 102 & 67 & 154 & 115 & 105 & 93 & 141 & 142 & 169 \\
Tukey & $\mathrm{ab}$ & $\mathrm{ab}$ & $\mathrm{a}$ & $\mathrm{a}$ & $\mathrm{ab}$ & $\mathrm{ab}$ & $\mathrm{ab}$ & $\mathrm{ab}$ & $\mathrm{ab}$ & $\mathrm{b}$ \\
S.spurium cf. 'Summer Glory' & 173 & 157 & 133 & 294 & 199 & 167 & 155 & 242 & 254 & 321 \\
Tukey & $-\mathrm{ab}$ & $\mathrm{a}$ & $\mathrm{a}$ & $\mathrm{d}$ & $\mathrm{abc}$ & $\mathrm{ab}$ & $\mathrm{a}$ & $\mathrm{bd}$ & $\mathrm{cd}$ & $\mathrm{d}$ \\
\hline
\end{tabular}

The first three months of the study, coinciding with the summer period, corresponded to the stabilization phase of the species. On the one hand, S. album, S. sediforme and S. sexangulare showed a slight increase in their mean area from $132 \mathrm{~cm}^{2}$ in June to 175 $\mathrm{cm}^{2}$ in September while S. spurium cf. 'Coccineum' and S. spurium cf. 'Summer Glory' were always below these values, with a decreasing trend. S. album showed significantly higher average individual area values than the two species of $S$. spurium in this period.

272 From September to October there was an increase in the average individual area in all the species that corresponded to a generalized decrease in average temperatures. Within this general increase, it was possible to differentiate two main trends, which were 275 maintained until the end of the study. On the one hand, S. album, S. sediforme and S. 
sexangulare, with an average value of $450 \mathrm{~cm}^{2}$, kept their area values stabilized until the following spring. On the other hand, the two varieties of $S$. spurium presented a significantly lower growth rate, with an average value of $224 \mathrm{~cm}^{2}$. These two tendencies were reflected in an autumnal growth in total area per species (Table 5), which continued until November for $S$. album $\left(2620.50 \mathrm{~cm}^{2}\right)$ and $S$. sexangulare $\left(2301.16 \mathrm{~cm}^{2}\right)$ and until December for $S$. sediforme $\left(2271.95 \mathrm{~cm}^{2}\right)$, while the two S. spurium stopped growing in October.

283 During the winter dormancy period, all Sedum species reduced their total coverage values (Table 5). The total area reduction rate during the winter period by species is as follows: S. sexangulare (12.33\%), S. album (14.36\%), S. sediforme (15.76\%), S. spurium cf. 'Coccineum' (39.47 \%) and S. spurium cf. 'Summer Glory' (47.18\%). However, in February, all the species reactivated their spring growth after the winter dormancy 288 (Figure 4 and Table 5).

289 The growth rates of the total area by species at the end of the experiment from highest 290 to lowest were as follows: S. sediforme (374.57\%), S. sexangulare (342.71\%), S. album 291 (241.10\%), S. spurium cf. 'Summer Glory' (85.47\%) and S. spurium cf. 'Coccineum' 292 (10.62\%).

293 Regarding monthly growth by species (Table 6), only S. album showed a significant increase during the first period (June-September).

295 S. album and S. sexangulare significantly increased their areas between September and 296 October and maintained them without significant changes until the end of the following 297 spring.

298 S. sediforme showed an oscillating growth rate from October to January and there was 299 a significant increase in growth in February.

300 S. spurium cf. 'Coccineum' was the species with the lowest growth. In the second period, 301 there was a non-significant increase in its area. In April, it had a new increase similar to 302 that of October. The growth of S. spurium cf. 'Summer Glory' had this same growth 303 pattern but in this case, the second growth period was statistically significant and started 304 in February.

305 Across the species, the largest increase in area percentage occurred in October and 306 February (Figure 5). Regarding the increase in area when compared to the initial values 307 (Figure 6), the same two trends which were observed in area evolution (Figure 4) can be 308 seen again: significantly higher growth rates in S. album, S. sediforme and S. 309 sexangulare as compared to the rates recorded in the two S. spurium varieties. It must 310 be highlighted that there were no statistically significant differences in the initial area (in 311 June) among the species. In the first 2 months, S. album, S. sediforme and $S$. 312 sexangulare showed a gradual increase (between $12 \%$ and $56 \%$ ) in their initial cover 313 area while the most important increase in their average area occurred in October (240 $314 \%$ in all three cases). However, in the case of S. spurium cf. 'Coccineum' and S. spurium 315 cf. 'Summer Glory', the first two months decreased their area by $42 \%$ and $23 \%$, 316 respectively. This loss of area was progressively recovered until February. 


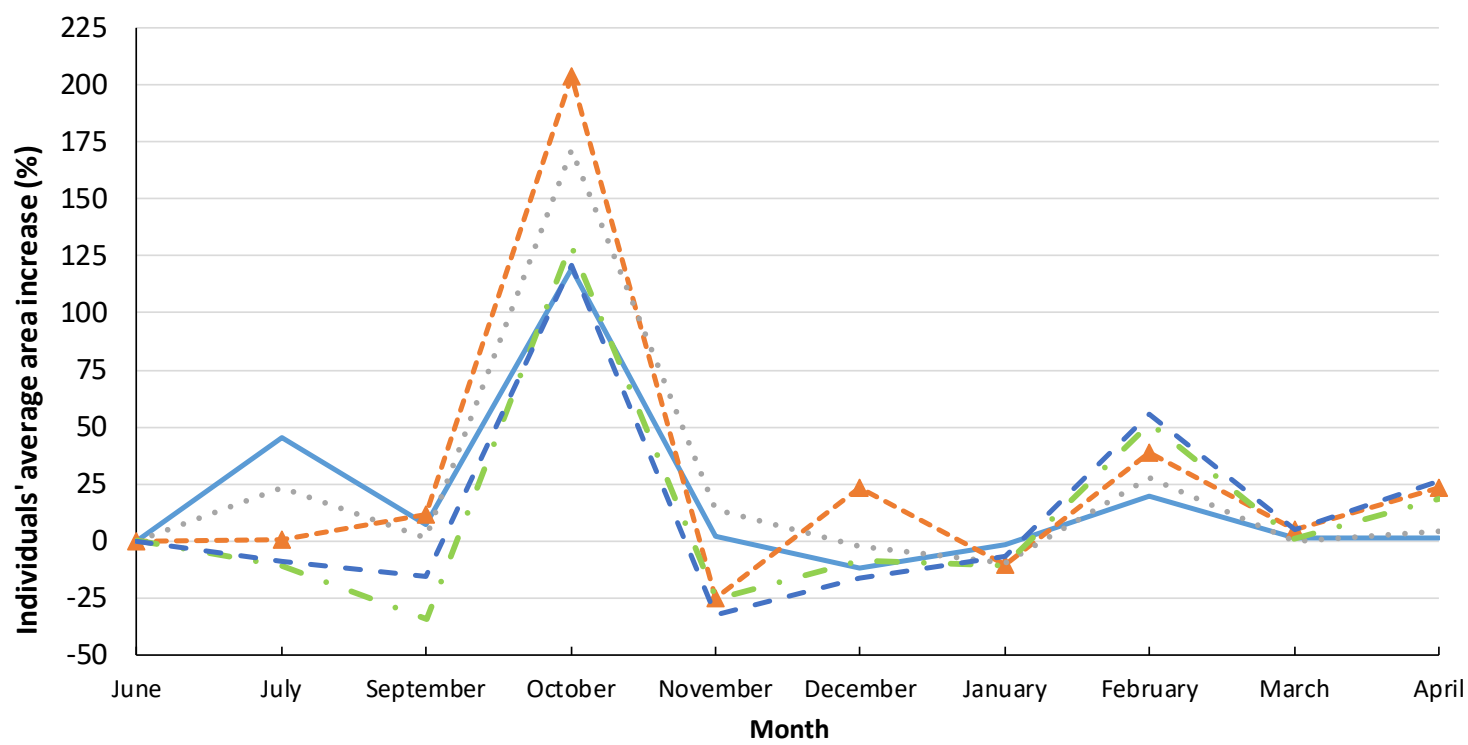

—S.album - - S.sediforme …S. S.sexangulare - S. spurium 'Coccineum' - - S.spurium 'Summer Glory'

Figure 5: Evolution of the monthly individuals' average area increase (in \%) in each studied species since the beginning of the experiment (June).

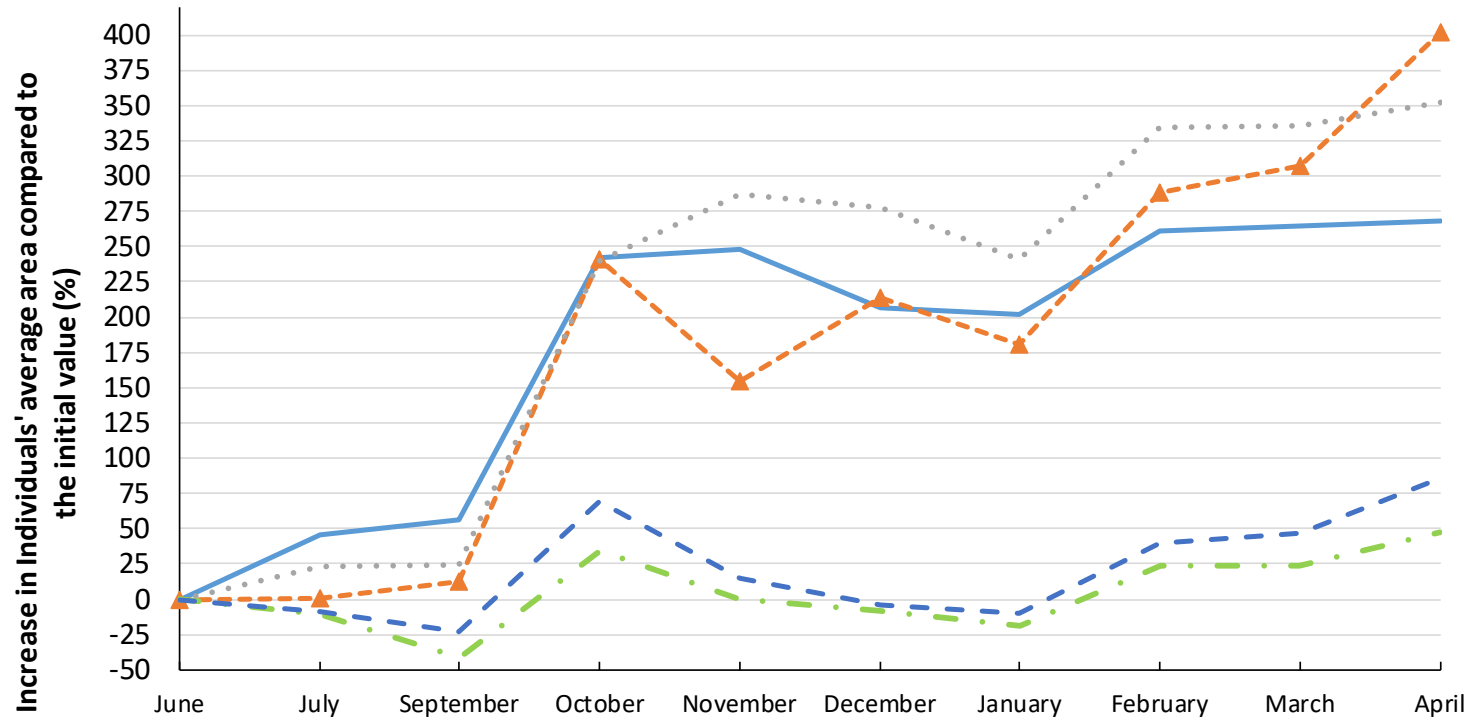
Month

Figure 6. Evolution of the increase in individuals' average area compared to the initial individuals' average area, by species.

\subsection{Shape Index (SI)}

Figure 7 shows the evolution of shape index (SI). At the beginning of the study all species had approximately irregular forms, such as dendritic, sinuous or elongated shapes (SI values above 2), particularly $S$. sediforme. During the first summer (from June to September), these complex forms maintained an average value of SI above 3. However, in the second growth period, from October to January, all the species, except S. spurium cf. 'Coccineum', simplified their shapes, achieving average values of SI close to 2 . The 
species that came closest to a circular form was $S$. album, especially from October to April. The trend of S. spurium cf. 'Coccineum', which increased its complex shape

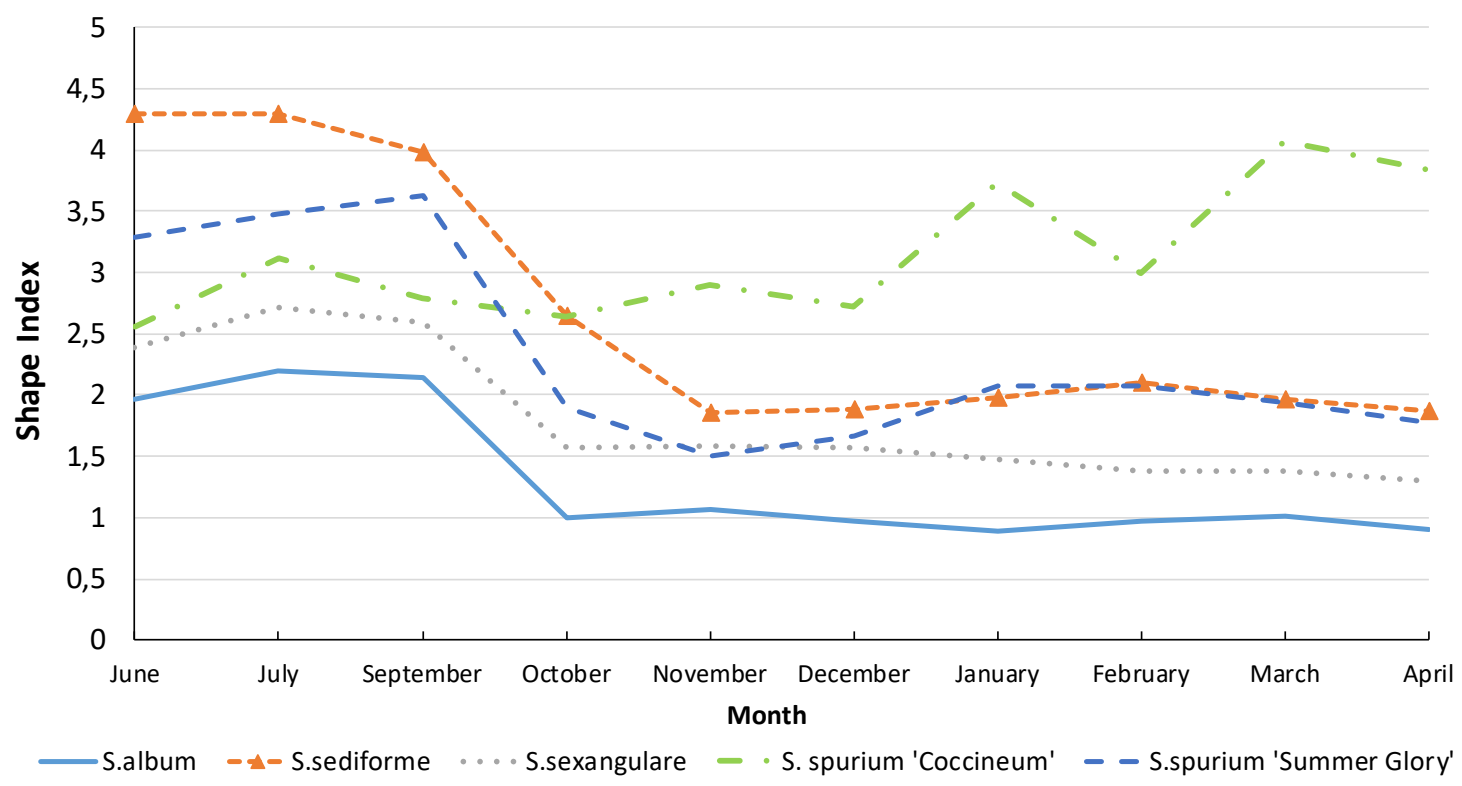

\section{Discussion}

\subsection{Suitability of the studied species for their use in extensive green roofs in a} continental Mediterranean climate

From the results of the study, it can be clearly observed that under Mediterranean climate conditions not all species traditionally used in green roofs are optimal for achieving the objectives of an extensive approach, i.e. short and soft roots, low maintenance, ability to withstand drought conditions, rapid multiplication, and of the self-generative type to achieve good ground coverage.

Among the five species studied, S. album and S. sexangulare were those with the best performance and adaptation to local conditions. This might mainly be a consequence of their superior surface coverage strategy, characterized not only by a high increase in area (bidimensional growth), but also a clear tendency toward growing in a spherical shape (a very compact form of tridimensional growth) (Fernández-Marín et al., 2017; Hernández et al., 2010; Medrano et al., 2008). It is known that different species survive and coexist using various functional strategies. Specifically, species' ability to respond to changes in water availability has been associated with morphological and physiological traits and constraints. In this context, drought-resistance plant traits have been synthesized into several functional classifications, on the basis of leaf habit, rooting structure, regeneration strategy or hydraulic traits, and drought architecture (Hernández et al., 2010).

363 On the other hand, S. sediforme, despite showing an increase in covered area similar to 364 that expressed by S. album and S. sexangulare, does not generate an optimal surface 365 coverage, since this increase was the consequence of its dispersion strategy by 
fragmentation, which leads to the establishment of new individuals from dispersed propagules (Lundholm et al. 2010; Lundholm et al. 2014; Dunnett et al., 2008). This specific strategy can also lie behind the oscillating growth rate showed by this species during the period from October to January.

370 It is worth highlighting that these three species were those which performed most successfully during the extremely limiting continental Mediterranean winter conditions. This behaviour is the result of the autochthonous component of $S$. album and $S$. sediforme, which are species well adapted to this climate and which can usually be found growing in exposed environments with thin soil layers and, consequently, subjected to freezing (Getter et al., 2007). On the other hand, S. sexangulare is native to central Europe, so it is well adapted to low winter temperatures (Getter et al., 2007).

Finally, the two tested varieties of $S$. spurium did not show any ability for optimal adaptation to the test conditions. Actually, these species did not significantly increase in coverage area and, in the case of S. spurium 'Coccineum', it tended to acquire very irregular shapes which were far from spherical form (Monterusso et al., 2005; FernándezMarín et al., 2017; Hernández et al., 2010). The red colour of $S$. spurium might also have affected its survival under continental Mediterranean conditions. According to some previous authors, leaf colour and chlorophyll content may affect canopy temperature and, indirectly, plant metabolism and dry matter production (Karageorgou and Manetas, 2006; Clark and Zheng, 2013). Although with controversial results, previous studies addressed the correlation between foliar anthocyanin content and resistance to biotic and abiotic agents, like fungi, herbivores, cold and excess of radiation (Karageorgou and Manetas, 2006). In studies conducted using Sedum spp. it was suggested that the occurrence of more yellow and red pigments might have been the result of resource reallocation during cold or drought stress periods (Clark and Zheng, 2013).

392

In this context, S. spurium, due to its red colour, may have had a lower photosynthetic rate and therefore be less competitive in a limited-resource and highly stressed environment, materialized as the lower covering rate which was recorded in the study.

\subsection{Implications of the results in extensive green roof designs}

After a year-long experiment in continental Mediterranean climate conditions, it can be stated that S. album, S. sexangulare and S. sediforme could be successful choices for the floristic palette of extensive green roofs. They comply with the requirements of these construction systems, i.e. minimal maintenance, self-generative typology, ability to withstand drought conditions, and achieve good surface coverage. Besides, $S$. sediforme ensures the valuable expansion of its populations through its high dispersion capacity.

403

404

In addition to their large development, in the case of $S$. album and $S$. sexangulare it is 405 worth highlighting their spherical growth pattern. This spherical shape is common in natural habitats exposed to extreme climatic conditions (Macek et al., 2016), and provides more optimal coverage, as well as a compact and dense foliage layer (Box, 1996; Macek et al., 2016). Consequently, it could provide a better provision of the associated ecosystem services, such as the shadow effect, noise reduction, pollution 410 absorption, etc. when compared to other kinds of development patterns that, with equal 
413

414

415

416

417

418

419

420

421

422

423

424

425

426

427

428

429

430

431

432

433

434

435

436

437

438

439

440

441

442

443

444

445

446

447
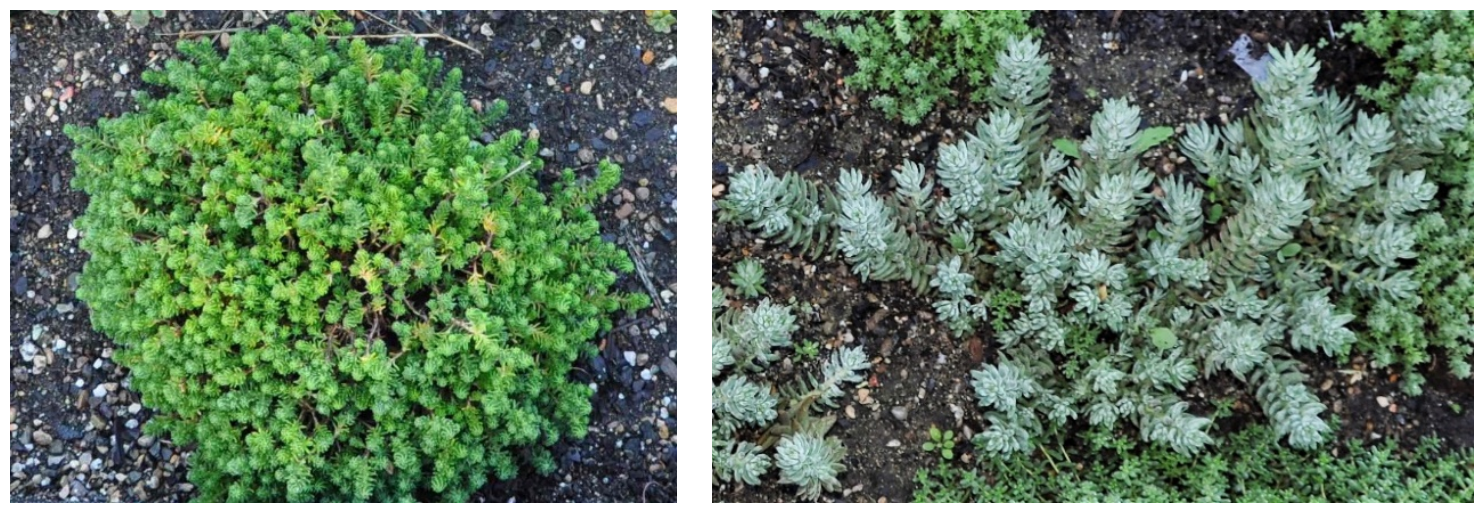

Figure 8. Sedum sexangulare and S. sediforme, two different growth strategies.

The use of S. spurium, especially the 'Coccineum' variety, would not be recommended for use on extensive green roofs in this climate. However, $S$. spurium might have a chance on semi-intensive and intensive green roofs where thicker substrate layers allow for the retention of higher quantities of water and provide more physical support and nutrients to the plants. In these cases, although the effective cover of $S$. spurium would not increase, it may prove able to survive in adverse conditions, especially in winter with minimal maintenance, providing aesthetic and landscape services. In addition, the irregular growth pattern, far from spherical, of S. spurium would provide multiple niches for the spontaneous colonization or controlled planting of various other species. Due to the related nursery effect (Van Mechelen et al., 2014), the inclusion of these species would help improve the green roof's design for aesthetic or landscaping purposes.

According to the European and Mediterranean Plant Protection Organization (EPPO), the use of autochthonous flora in gardening and botanical gardens is recommended (Heywood and Sharrock, 2013). The successful performance of Sedum species in extreme climates, such as the dry continental Mediterranean climate, has been evaluated in the present study. Its results would support the inclusion of autochthonous plants in green roof designs in accordance with EPPO recommendations, therefore optimizing roof sustainability and avoiding the use of exotic species in urban gardening.

\subsection{Seasonal considerations of the results for green roof establishment}

After planting in May, the plants faced the most stressful period of the year due to the high temperatures. The tested species of Sedum took about three months to completely adapt to its new location under continental Mediterranean conditions. This result has implications for the future design and implementation on Sedum-based extensive green roofs in Mediterranean environments, since depending on the planting date, adaptation timing may vary.

It has been proven that once the species have adapted to their new conditions, they are able to resist future periods of adversity, in this case, hard winter conditions. Hence, it indicates the importance of planning the dates of planting in new green roof projects in this climate (Getter and Rowe, 2008; Fioretti et al., 2010). 


\section{Conclusions}

449 In the present study, five species of Sedum commonly used on extensive green roofs 450 (Sedum album (White stonecrop), S. sediforme (Pale stonecrop), S. sexangulare 451 (Tasteless Stonecrop). S. spurium (Two-row stonecrop) cf. 'Coccineum' and S. spurium 452 cf. 'Summer Glory' were studied for a more than one-year period with the aim of 453 characterizing their growth and development patterns under dry continental 454 Mediterranean climate conditions. The main purpose was to gain knowledge about their 455 individual potential in contributing to plant coverage, green roof sustainability, and linked 456 ecosystem services.

457

458 From the results, and taking the extensive conditions of study into account, it can be 459 concluded that:

460

461

462

463

464

465

466

467

468

469

470

471

472

473

474

475

476

477

478

479

480

481

482

483

484

485

486

487

488

489

490

491

492

- S. album. S. sexangulare. S. sediforme perform suitably under the extreme climate conditions of a continental Mediterranean climate (Csa; warm temperate; dry summer; hot summer), showing a great capacity for colonization and coverage. Therefore, they can be recommended for use in this climate.

- On the other hand, both tested varieties of Sedum spurium, cf. 'Coccineum' and cf. 'Summer Glory' although seeming to have suitable characteristics for their use in green roofs, did not develop successfully in the extensive conditions of the study, especially the 'Coccineum' variety. Consequently, the recommendation might be to use these two species as part of a more complete palette of other more suitable ones, or in other, less extreme conditions (semi-intensive green roofs, irrigation systems to support the plants, etc.).

- The use of the Shape Index (SI) could be an adequate tool for decision-making in the selection of plant species in the design of green roofs, because it provides information not only about the shape and size but also on the growth strategy of each species, and therefore their performance relating to the coverage potential and green roof development.

This study is the first approach to the analysis of the growth and development of Sedum species that form part of extensive green roofs in Mediterranean conditions, and has yielded results of relevant significance. However, it is expected to be further optimized by increasing the space between individuals in order to delay the fusion of the species, allowing the growth dynamics to be rehearsed over longer periods and to obtain a more in-depth analysis of temporal variations on the perimeter of the species.

For further studies, the establishment of minimal irrigation support under maximum water stress conditions has been proposed in order to ensure the survival of less well-adapted species. This could offer new alternatives for the selection of extensive green roof species in situations where irrigation support might be possible.

Likewise, conducting studies on the three-dimensional structure of Sedums, and other species currently used on green roofs, is recommended in order to obtain more information on their actual behaviour. Such studies would also provide more insight into 
these species' contributions to suitable green roof development (degree of coverage, the nursery effect, etc.) and the provision of related ecosystem services (the cooling effect of evapotranspiration, the shadow effect, etc.).

Finally, further studies on the influence of Sedum pigmentation on the performance of these species and on the development of the whole green roof must be carried out. The differences in colour between species, the changes in pigmentation through development stages, as well as the seasonal changes due to the climate influence, are aspects that would be worth studying in an in-depth manner in the future. It would also be wise to consider the misinterpretations which this factor can provoke when determining the true type of Sedum used in every single project and the following consequences on green roof development and functionality.

505

\section{Acknowledgements}

507 This work is partially funded by the Spanish government ENE2015-64117-C5-1-R 508 (MINECO/FEDER). The authors would like to thank the Catalan Government for the 509 quality accreditation given to their research group (2017 SGR 1537). GREiA is a certified TECNIO agent in the category of technology developers by the Government of Catalonia. Julià Coma would like to thank the Ministerio de Economia y Competitividad de España for the Juan de la Cierva Grant, FJCl-2016-30345. The authors also want to thank the botanic garden of Lleida, Arborètum Dr. Pius Quer i Font, and the company Buresinnova S.A (C/Saragossa, 95 Entsol 3a, 08006 BARCELONA) for their technical support and collaboration in this study.

516

\section{References}

1. Agra H., Klein T., Vasl A., Kadas G., Blaustein L., 2017. Measuring the effect of plantcommunity composition on carbon fixation on green roofs. Urban Forestry \& Urban Greening 24, 1-4. DOI: http://dx.doi.org/10.1016/j.ufug.2017.03.003

2. Azeñas V., Cuxart J., Picos R., Medrano H., Simó G., López-Grifol A., Gulías J., 2018. Thermal regulation capacity of a green roof system in the mediterranean region: The effects of vegetation and irrigation level. Energy \& Buildings 164, 226-238. DOI: https://doi.org/10.1016/j.enbuild.2018.01.010

3. Barker K.J., Lubell J.D., 2012. Effects of species proportions and fertility on SedumSedum green roof modules. HorTechnology 22 (2), 196-200

4. Bates A.J., Sadler J.P., Mackay R., 2013. Vegetation development over four years on two green roofs in the UK. Urban Forestry \& Urban Greening 12, 98-108. DOI: http://dx.doi.org/10.1016/j.ufug.2012.12.003

5. Benvenuti S., Bacci D., 2010. Initial agronomic performances of Mediterranean xerophytes in simulated dry green roofs. Urban Ecosystems 13 (3) 349-363. DOI: http://dx.doi.org/10.1007/s11252010-0124-129

6. Bevilacqua P., Coma J., Pérez G., Chocarro C., Juárez A., Solé C., De Simone M., Cabeza L.F., 2015. Plant cover and floristic composition effect on thermal behaviour of extensive green roofs. Building and Environment 92, 305-316. DOI: http://dx.doi.org/10.1016/j.buildenv.2015.04.026 
7. Box Elgene O., 1996. Plant functional types and climate at the global scale. Journal of Vegetation Science 7: 309-320. DOI: https://doi.org/10.2307/3236274

8. Butler C., Orians C.M., 2011. Sedum cools soil and can improve neighbouring plant performance during water deficit on a green roof. Ecological Engineering 37, 1796-1803. DOI: http://dx.doi.org/10.1016/j.ecoleng.2011.06.025

9. Clark M.J., Zheng Y., 2012. Evaluating fertilizer influence on overwintering survival and growth of SedumSedum species in a fall-installed green roof. HortScience 47 (12), 17751781. DOI: https://doi.org/10.21273/HORTSCI.47.12.1775

10. Clark M.J., Zheng Y., 2013. Plant nutrition requirements for an installed Sedum-vegetated green roof module system: Effects of fertilizer rate and type on plant growth and leachate nutrient content. HortScience 48 (9), 1173-1180. DOI: https://doi.org/10.21273/HORTSCI.48.9.1173

11. Coma J., Pérez G., Solé C., Castell A., Cabeza L.F., 2016. Thermal assessment of extensive green roofs as passive tool for energy savings in buildings. Renewable Energy 85, 11061115. DOI: http://dx.doi.org/10.1016/j.renene.2015.07.074

12. Dunnett N., Nagase A., Hallam A., 2008. The dynamics of planted and colonising species on a green roof over six growing seasons 2001-2006: influence of substrate depth. Urban Ecosyst 11, 373-384. DOI: http://dx.doi.org/10.1007/s11252-007-0042-7

13. Durhman K., Rowe D.B., 2007. Effect of substrate depth on initial growth, coverage, and survival of 25 Succulent green roof plant taxa. HortScience 42 (3) 588-595. DOI: https://doi.org/10.21273/HORTSCI.42.3.588

14. Dvorak B., Volder A., 2013. Rooftop temperature reduction from unirrigated modular green roofs in south-central Texas. Urban Forestry \& Urban Greening 12, 28- 35. DOI: http://dx.doi.org/10.1016/j.ufug.2012.05.004

15. Emilsson T., Rolf K., 2005. Comparison of establishment methods for extensive green roofs in southern Sweden. Urban Forestry \& Urban Greening 3, 103-111. DOI: http://dx.doi.org/10.1016/j.ufug.2004.07.001

16. Emilsson T., 2008. Vegetation development on extensive vegetated green roofs: Influence of substrate composition, establishment method and species mix. Ecological engineering 33, 265-277. DOI: http://dx.doi.org/10.1016/j.ecoleng.2008.05.005

17. European Commission, 2015. Directorate-General for Research and Innovation. Directorate I - Climate Action and Resource Efficiency. Unit I.3 - Sustainable Management of Natural Resources. Nature-Based Solutions \& Re-Naturing Cities. Final Report of the Horizon 2020 Expert Group on 'Nature-Based Solutions and Re-Naturing Cities' 2015

18. Fernández-Marín B., Hernánde, A., Garcia-Plazaola J.I., Esteban R., Míguez F., Artetxe U., Gómez-Sagasti M.T., 2017. Photoprotective strategies of Mediterranean plants in relation to morphological traits and natural environmental pressure: A meta-analytical approach. Plant Science, 8 (1051). DOI: https://doi.org/10.3389/fpls.2017.01051

19. FLL-“Guidelines for the Planning, 2008. Construction and Maintenance of Green Roofing. Green Roofing Guideline". The Landscape Development and Landscaping Research Society e. V. (FLL)

20. Fioretti R., Palla A., Lanza L.G., Principi P., 2010. Green roof energy and water related performance in the Mediterranean climate. Building and Environment. 45, 1890-1904. DOI: https://doi.org/10.1016/j.buildenv.2010.03.001

21. Getter K., Kristen L., Rowe D.B., 2007. Effect of substrate depth and planting season on Sedum plug survival on green roofs. Journal of Environmental Horticulture 25 (2), 95-99.

22. Getter K.L., Rowe D.B., 2008. Media depth influences Sedum green roof establishment. Urban Ecosystems. 11, 361-372. DOI: https://doi.org/10.1007/s11252-008-0052-0.

23. Getter K., Rowe D.B., 2009. Substrate depth influences Sedum plant community on a green roof. HortScience 44 (2), 401-407. DOI: https://doi.org/10.21273/HORTSCI.44.2.401

24. Getter K.L., Rowe D.B., Cregg B.M., 2009. Solar radiation intensity influences extensive green roof plant communities. Urban Forestry \& Urban Greening 8, 269-281. DOI: http://dx.doi.org/10.1016/j.ufug.2009.06.005 
25. Gyenizse P., Bognár Z., Czigány S., Elekes T., 2014. Landscape shape index as a potential indicator of urban development in Hungary. Landscape \& Environment 8 (2), 78-88.

26. Heim A., Lundholm J., 2014. The effects of substrate depth heterogeneity on plant species coexistence on an extensive green roof. Ecological Engineering 68, 184-188. DOI: http://dx.doi.org/10.1016/j.ecoleng.2014.03.023

27. Hernández E.I., Vilagrosa A. Pausas J.G. Bellot J. 2010. Morphological traits and water use strategies in seedlings of mediterranean coexisting species. Plant Ecology 207 (2), 233-244. DOI: https://doi.org/10.1007/s11258-009-9668-2

28. Heywood V., Sharrock S., 2013. European Code of Conduct for Botanic Gardens on Invasive Alien Species. Council of Europe, Strasbourg, Botanic Gardens Conservation International, Richmond

29. Karageorgou P., Manetas Y., 2006. The importance of being red when young: anthocyanins and the protection of young leaves of Quercus coccifera from insect herbivory and excess light. Tree Physiology 26, 613- 621

30. Köhler M., 2006. Long-term vegetation research on two extensive green roofs in Berlin. Urban Habitats 4 (1) 1541-7115

31. Kottek M., Grieser J., Beck C., Rudolf B., Rubel F., 2006. World Map of the Köppen-Geiger climate classification updated. Meteorol. Z., 15, 259-263. DOI: http://dx.doi.org/10.1127/0941-2948/2006/0130

32. Lundholm J., Maclvor J.S., MacDougall Z., Ranalli M., 2010. Plant species and functional group combinations affect green roof ecosystem functions. PLoS ONE 5 (3) e9677. DOI: http://dx.doi.org/10.1371/journal.pone.0009677

33. Lundholm J., Heim A., Tran S., Smith T., 2014. Leaf and life history traits predict plant growth in a green roof. Ecosystem. PLoS ONE 9 (6), e101395. DOI: https://doi.org/10.1371/journal.pone.0101395

34. Macek P., Prieto I., Macková J., Pistón N., Pugnaire F.I., 2016. Functional plant types drive plant interactions in a Mediterranean mountain range. Plant Science 7, 662. DOI: https://doi.org/10.3389/fpls.2016.00662

35. Maclvor J.S., Margolis L., Puncher C.L., Carver Matthews B.J., 2013. Decoupling factors affecting plant diversity and cover on extensive green roofs. Journal of Environmental Management 130, 297-305. DOI: http://dx.doi.org/10.1016/j.jenvman.2013.09.014

36. Mc Garigal K., Marks B. J., 1995. FRAGSTATS: spatial pattern analysis program for quantifying landscape structure. US Forest Service General Technical Report PNW 351: 103-104.

37. Medrano H., Flexas J., Galmes J., 2008. Variability in water use efficiency at the leaf level among Mediterranean plants with different growth forms. Plant and Soil 317, 17-29. DOI: https://doi.org/10.1007/s11104-008-9785-z

38. Monterusso M.A., Rowe D.B., Rugh C.L., 2005. Establishment and persistence of SedumSedum spp. and native taxa for green roof applications. HortScience 40 (2) 391-396. DOI: https://doi.org/10.21273/HORTSCI.40.2.391

39. Moritani S., Yamamoto T., Andry H., Inoue M., Kato K., Saito H., 2013. Effect of combined water and salinity stress factors on evapotranspiration of Sedum kamtschaticum Fischer in relation to green roof irrigation. Urban Forestry \& Urban Greening 12, 338-343. DOI: http://dx.doi.org/10.1016/j.ufug.2013.04.005

40. Nagase A., Dunnett N., 2010. Drought tolerance in different vegetation types for extensive green roofs: Effects of watering and diversity. Landscape and Urban Planning 97, 318-327. DOI: http://dx.doi.org/10.1016/j.landurbplan.2010.07.005

41. Nagase A., Dunnett N., 2013. Performance of geophytes on extensive green roofs in the United Kingdom. Urban Forestry \& Urban Greening 12, 509-521. DOI: http://dx.doi.org/10.1016/j.ufug.2013.06.005

42. Nektarios P.A., Ntoulas N., Nydrioti E., Kokkinou I., Bali EM., Amountzias I., 2015. Drought stress response of SedumSedum sediforme grown in extensive green roof systems with 
different substrate types and depths. Scientia Horticulturae 181, 52-61. DOI: http://dx.doi.org/10.1016/j.scienta.2014.10.047

43. Ondoño S., Martínez-Sánchez J.J., Moreno J.L., 2015 Evaluating the growth of several Mediterranean endemic species in artificial substrates: Are these species suitable for their future use in green roofs?. Ecological Engineering 81, 405-417. DOI: http://dx.doi.org/10.1016/j.ecoleng.2015.04.079

44. Pérez G., Vila A., Solé C., Coma J., Castell A., Cabeza L.F., 2015. The thermal behaviour of extensive green roofs under low plant coverage conditions. Energy Efficiency 8 (5) 881-894. DOI: http://dx.doi.org/10.1007/s12053-015-9329-3

45. Pérez G., Perini K., 2018. Nature Based Strategies for Urban and Building Sustainability. 1st Edition. Imprint: Butterworth-Heinemann. Elsevier. eBook ISBN: 9780128123249. Paperback ISBN: 9780128121504

46. Rasband, W.S., ImageJ, U. S. National Institutes of Health, Bethesda, Maryland, USA, https://imagej.nih.gov/ij/, 1997-2018

47. Rowe D.B., Getter K-L., Durhman A.K., 2012. Effect of green roof media depth on Crassulacean plant succession over seven years. Landscape and Urban Planning 104, 310319. DOI: http://dx.doi.org/10.1016/j.landurbplan.2011.11.010

48. Rayner J.P., Farrell C., Raynor K.J., Murphy S.M., Williams N.S.G., 2016. Plant establishment on a green roof under extreme hot and dryconditions: The importance of leaf succulence in plant selection. Urban Forestry \& Urban Greening 15, 6-14. DOI: http://dx.doi.org/10.1016/j.ufug.2015.11.004

49. Starry O., Lea-Cox J.D., Kim J., van lersel M.W., 2014. Photosynthesis and water use by two SedumSedum species in green roof substrate. Environmental and Experimental Botany 107, 105-112. DOI: http://dx.doi.org/10.1016/j.envexpbot.2014.05.014

50. Thuring C.E., Berghage R.D., Beattie D.J., 2010. Green roof plant responses to different substrate types and depths under various drought conditions. HorTechnology 20 (2), 395401. DOI: https://doi.org/10.21273/HORTTECH.20.2.395

51. Van Mechelen C., Dutoit T., Hermy M., 2014. Mediterranean open habitat vegetation offers great potential for extensive green roof design. Landscape and Urban Planning 121, 81-91. DOI: http://dx.doi.org/10.1016/j.ecoleng.2014.03.043

52. Van Woert N.D., Rowe D.B., Andresen J.A., Rugh C.L., Xiau L., 2005. Watering regime and green roof substrate design affect Sedum plant growth. HortScience 40 (3) 659-664. DOI: https://doi.org/10.21273/HORTSCI.40.3.659

53. Vijayaraghavan K., 2016. Green roofs: A critical review on the role of components. benefits. limitations and trends. Renewable and Sustainable Energy Reviews. 57. 740-752. DOI: http://dx.doi.org/10.1016/j.rser.2015.12.119

54. Wolf D., Lundholm J.T., 2008. Water uptake in green roof microcosms: Effects of plant species and water availability. Ecological engineering 33 179-186. DOI: http://dx.doi.org/10.1016/j.ecoleng.2008.02.008

55. Wong N.H., Tan P., Chen Y., 2007. Study of thermal performance of extensive rooftop greenery systems in the tropical climate. Building and Environment 42, 25-54. DOI: http://dx.doi.org/10.1016/j.buildenv.2005.07.030 